УДК

DOI:

Богдан Щурик, дочент кафедри народних музичних інструментів та вокалу Дрогобииького державного педагогічного університету імені Івана Франка

\title{
ТЕОРЕТИЧНІ АСПЕКТИ ПІДГОТОВКИ СТУДЕНТІВ ДО МУЗИЧНО-ПЕДАГОГІЧНОЇ ДІЯЛЬНОСТІ
}

У статті висвітлюється професія музичного вчителя серед вічних професій саме учительська посідає особливе місие: вона початок усіх. Змінюються умови $і$ засоби виховання, та незмінним залишається призначення вчителя - навчити людину і не тільки математики чи історії, але ймузичного мистецтвв.

Педагог має справу з дітьми і його завданням є підготовка підростаючого покоління, до активноі участі у житті суспільства. Для того, щуоб нові покоління могли включитися у різні сфери життя - розвивати науку, мистеитво, виробляти продукиію, поширювати досвід, вони проходять попередній шлях людства $i$ засвоюють ті результати, яких вони досягли впродовж тисячоліть.

Ключові слова: професія вчителя; музична освіта; учень; музично-виховні завдання; педагогічний етикет; “накопичення знань”; спілкування.

Puc. 1. Jim. 6.

Bohdan Shchuryk, Associate Professor of the Folk Musical Instruments and Vocals Department Drohobych Ivan Franko State Pedagogical University

\section{THEORETICALASPECTS OF PREPARATION OF STUDENTS TO MUSIC AND PEDAGOGICALACTIVITIES}

The article highlights the profession of musical teacher. Among the eternal professions the teacher holds a special place: it is the beginning of all professions. The conditions and means of education are changing, but the purpose of the teacher remains unchanged - to teach a person and not only mathematics or history, but also musical art.

The teacher deals with children and his task is to prepare the young generation for active participation in society. In order to the new generations can engage into different spheres of life-to develop science, art, produce products, disseminate experience, they pass the previous path of mankind and master the results that they have achieved over the millennia.

The main responsibility of a teacher consists in transferring the cognitive experience, helping students to acquire knowledge, skills. Lack of purposeful musical education can lead to both intellectual and moral degradation of new generations. The teacher has a social responsibility for the consequences of his work. Especially important is the mission of the teacher in our time. The position of the teacher of musical art has always been and is specific. He prepares his pupils for the needs of the time, to the specific demands of society. On the other hand, the teacher objectively remaining the bearer and leader of culture, participates in the formation of personality. A teacher is a person who is directed to the future, and forms young people with an active and responsible aspiration to renew the world in which they live. What does a pupil expect from a teacher of musical art, who is he for him? First of all, he is the carrier of knowledge of world and Ukrainian musical culture, as well as an example for imitation. But the student waits for a teacher and an understanding of their problems, aspirations. By attracting a student to music, the teacher directs him to the knowledge of musical art and himself in it.

Keywords: a profession of teacher; musical education; a student; musical-educational tasks; pedagogical etiquette; accumulation of knowledge; communication

П остановка проблеми. Музичнопедагогічна діяльність може бути професійною і непрофесійною. Непрофесійною діяльністю займаються всі люди в повсякденному житті, не маючи спеціальної музичної освіти і педагогічної кваліфікації. Здійснюючи виховний вплив, вони діють здебільшого інтуїтивно, не завжди вміючи чітко пояснити чи обгрунтувати свою позицію.

Професійна музично-педагогічна діяльність потребує спеціальної освіти і здійснюється у спеціальних навчально-виховних та освітніх закладах, загальноосвітніх школах, музичних школах і т.д. Фахівець діє свідомо, спираючись на систему принципів, правил, прийомів. У музично-педагогічній діяльності для професіонала замало лише компетентності та системи знань, володіння голосом та музичним інструментом. Потрібні певні особистісні якості, в першу чергу - його душа.

Таким чином визначаючи професію вчителя музичного мистецтва в такому розумінні - це авторитетна мудра людина, яка має великий вплив на людей, а у вузькому - це спеціаліст, що веде 
музично-навчальну і виховну роботу з учнями у школах різних типів.

Музично-педагогічна діяльність включає різні галузі педагогічної науки. Дидактика вивчає загальні закономірності навчання. Методика розробляє ефективні способи викладання музичних предметів. Теорія виховання визначає принципи і закономірності виховного впливу вчителя на учня.

Аналіз актуальних досліджень. Основою нашого дослідження стали праці педагогів О. Вишневський, С. Гончаренко, В. Кан-Калик, А. Макаренко, І. Язюка, В. Сухомлинського.

У своєму дослідженні О. Вишневський наголошує системний аналіз процесу едукації має починатися 3 визначення чинників зайнятих у ньому. Ними є найперше педагог, учень і предмет (рис 1.)
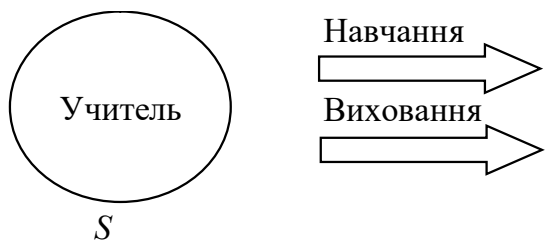

Рис. 1. Традиційне трактування

Особливість музично-педагогічної діяльності полягає також у тому, що вона є діяльністю сумісною, яка відбувається за законами спілкування. Учитель і учень постають як суб'єкти спілкування, тому пасивність хоча б одного $з$ них призводить до порушення контакту і зрештою до зниження ефективності музичнопедагогічної діяльності. 3 цього погляду навчання i виховання виступає як творче спілкування вчителя та учня, результатом якого є формування не тільки музичних знань і вмінь, а й системи ставлення учня до себе, до інших, до світу. Звичайно, під час спілкування зміни відбуваються як в особистості учня, так і в особистості вчителя. Зростає педагогічна майстерність вчителя та соціальна зрілість. На вчителя покладено обов'язки не тільки учасника діалогу, а й організатора творця. Загальна стратегія вчителя полягає в тому, щоб сформувати учня як суб' єкта навчальної діяльності і спілкування.

Таким чином, музична педагогіка дає можливість залучати учнів до процесу творення самих себе. Важливу роль у досягненні результатів відіграє особистість педагога, його талант, фахова підготовка, професійна самосвідомість та сформованість індивідуального стилю діяльності.

Змістом професійної музично-педагогічної діяльності $є$ керівництво діяльністю учнів у навчально-виховному процесі, а головною метою - розвиток творчої особистості дитини.

Мета статті $є$ ознайомлення діяльності педагога - формування творчої особистості учня в процесі навчання та виховання. Визначити творчий характер діяльності вчителя низкою чинників.

Виклад основного матеріалу Суть особливої позиції вчителя музики в системі взаємодії з учнями полягає в тому, щоб організувати і контролювати діяльність учня, який є об'єктом власної навчально-пізнавальної діяльності. Методика розробляє ефективні способи викладання конкретних предметів: диригування, співу, гри на музичному інструменті. Теорія виховання визначає принципи i закономірності виховного впливу вчителя на учня. Метою педагогічної діяльності $є$ виховання навиків

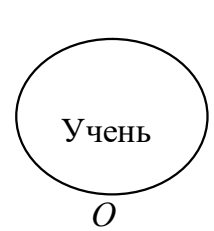

$$
\begin{aligned}
& \mathrm{S}-\text { cуб }^{\prime} \epsilon \kappa m \\
& O-о \sigma^{\prime} \epsilon \kappa m
\end{aligned}
$$

структури навчального процесу [1]

і вмінь підростаючого покоління, формування творчої особистості учня в процесі навчання i виховання.

Діяльність вчителя музики передбачає не лише відтворення внутрішнього світу учня, а й активне та цілеспрямоване його перетворення відповідно до мети виховання й навчання. Таким чином, завдання вчителя полягає у створенні умов, які стимулювали б цю активність.

Кожен вчитель має свої професійні музичновиховні завдання, які зумовлюють вибір системи керування діяльністю учня. Відомі такі види професійно-педагогічних завдань: вчитель навчає, а учні вчаться; вчитель вже знає, а учень не знає нічого; вчитель говорить, а учні мусять його слухати; вчитель карає, а учні мають йому підкоритися.

Отже, професійна музично-педагогічна діяльність має формуватися таким чином, що вчитель вбачає в учневі активного суб'єкта навчання, розвиває музичні здібності учня з самокеруванням власною діяльністю, організовує навчання як розв'язання навчально-пізнавальних проблем. Вчитель добирає зміст, методи навчання, а також вибирає форми спільної діяльності з учнями.

Різноманітність індивідуальних музичних особливостей учнів, які залучені до педагогічної взаємодії та нестандартність педагогічних 
ситуацій, в межах яких відбувається взаємодія, визначають творчий характер музичнопедагогічної діяльності.

Завдання педагога музичного мистецтва полегшувати учням процес розвитку музичних здібностей, створювати для них умови сприйняття та відтворення музики та всіляко сприяти досягненню повного творчого самовиявлення.

Педагогічний етикет - це сукупність правил і моделей моральної поведінки педагога в типових ситуаціях та обставинах педагогічної діяльності. Педагогічний етикет характеризує зовнішній прояв ставлення педагога до власної праці, до учня, до учнівського колективу, до батьків учнів, до свого колеги, до педагогічного колективу, до керівництва, до себе, до своєї держави [2].

Розповідь педагога посідає вагоме місце в навчально-вихованомупроцесі, зокрема, на уроках музичного мистецтва.

О. Кан-Калік трактує педагогічне спілкування, як індивідуально-типологічні особливості соціально-психологічної взаємодії вчителя 3 учнями [3].

Думку потрібно викласти доступною мовою, подбавши про те, щоб мета інформування була зрозумілою учням. Для переконання треба домогтися не лише сприйняття інформації, а й згоди з нею, а це потребує зняття упередженості в учнів.

Педагог, розповідаючи, має домогтися, щоб не лише зміст, а й мета розповіді про композитора чи музичні явища були зрозумілі й сприйняті учнями. При цьому педагог мусить враховувати те, як учень сприймає його слово. Дослідження показують, що слухання - це складний процес, адже увага легко розпорошується. Активне слухання має забезпечити роботу думки, уяви, пам'яті, а від темпу викладу залежить створення умов для цього. Важко бути уважним, коли розповідають нудно, але ще важче слухати коли розповідь дуже цікава. Отже, вчитель музики має вбачати у своїй роботі різні завдання: ознайомлення з інформацією, спонукання до слухання, керування увагою, осмислення почутого. Крім того, педагог має водночас аналізувати свою діяльність, зміст, методику у зв'язку з проблемами, що виникають під час сприймання інформації.

А.С. Макаренко у своїй статті “Деякі висновки 3 мого педагогічного досвіду” вперше характеризував поняття “майстерність вихователя” i “педагогічна техніка”. Він розглядає проблему педагогічної майстерності педагога як проблему створення єдиного виховного колективу, здатного утверджувати дисципліну як дійсну свободу особистості, як форму життя та діяльності, як засіб захищеності, повноправ’я особистості в колективі [4].

Педагогічна майстерність і особистість вчителя. Що притаманне праці педагогамайстра? Майстерність завжди розкривається в ефективній діяльності. Науковці визначають майстерність як найвищий рівень педагогічної діяльності; “високе мистецтво виховання i навчання”; “синтез наукових знань, умінь і навичок музичного мистецтва та особистих якостей учителя".

В.О. Сухомлинський про роль психічної саморегуляції в діяльності педагога. Способи управління психічним станом під час налаштування на публічну діяльність і в умовах іï здійснення: виховання доброзичливості й оптимізму, вияв позитивної установки на спілкування; контроль власного фізичного стану (регуляція м'язового напруження, зміна темпу мовлення та рухів); розрядка від негативних емоцій за допомогою створення зони захисного збудження; управління увагою, переключення і концентрація їі на меті і надзавданні діяльності; звернення до власного почуття обов'язку; аутотренінг, його етапи, доцільні формули самонавіювання. Важливість для педагога формування саногенного мислення [6].

Справді, зовні майстерність виявляється в успішному розв'язанні педагогічних завдань, високому рівні організованого навчальновиховного процесу, та сутність іiі в тих якостях особистості вчителя, які породжують цю діяльність, забезпечують їі успішність. Сутність музично-педагогічної майстерності - в особистості вчителя, в його позиції, здатності виявляти творчу ініціативу на підставі реалізації власної системи цінностей. Майстерність - вияв найвищої форми активності особистості у використанні методів і засобів взаємодії у кожній конкретній ситуації навчання і виховання.

Для того, щоб здійснювати керівництво розвитком учнів, учитель музики має бути здатним керувати собою і через себе - усіма компонентами педагогічної діяльності.

Спрямованість на дитину як прагнення співучасті у її розвитку дає змогу обрати мету i спонукає до пошуку способів її реалізації педагогічних технологій і техніки.

Втрата вчителем здатності регулювати педагогічний процес призводить до гальмування гармонійного розвитку його взаємодії з учнями.

Отже, майстерність вчителя можна розглядати як найвищий рівень педагогічної діяльності, як вияв творчої активності педагога. 
Особливості педагогічної діяльності. Діяльність педагога музичного мистецтва спрямована на особистість іншої людини, утвердження словом, музикою і працею високих духовних цінностей, моральних норм поведінки і стосунків. Це вияв професійної ідеології вчителя, його ставлення до музично-педагогічної дійсності, іiі мети, змісту і засобів.

Проаналізуємо, з чим іде вчитель на урок музичного мистецтва? Він заходить 3 думкою виконати програму, подати матеріал за 45 хв. I якщо досвідчений педагог буде намагатися допомогти кожному переможно засвоювати знання, то вчитель-початківець прагне, щоб діти вбачали в ньому вчителя в більшості випадків. Вчитель повинен на уроці разом 3 дітьми пізнавати красу слова, музики, думки, життя, навчити їх жити 3 серцем, рости і жити громадянами.

Отже, педагогічна спрямованість особистості кожного вчителя, багато перспективна: це і самоутвердження - щоб вбачали в ньому кваліфікованого, вимогливого, справжнього вчителя; і засоби педагогічного впливу, коли головне для вчителя - програма і способи засвоєння.

Для педагога провідною є орієнтація на головну мету за гармонійної узгодженості усіх інших: гуманізація діяльності, гідного самоутвердження, доцільності засобів, врахування потреб вихованців. Лише за умови почуття відповідальності перед майбутнім, усвідомлення мети і великої любові до дітей починає формуватися педагогічна діяльність вчителя.

Гуманістична спрямованість педагога визначає стратегію його уроку: що головне 3'ясування біографічних відомостей про композитора або письменника, чи роздуми про сенс життя, вибір шляху, над чим замислюються й учні? Основою музично-педагогічної діяльності $\epsilon$ професійна компетентність, знання і вміння вчителя звернені, з одного боку, до уроку музики, які він викладає, а з іншого - до учнів, психологію і музичні здібності яких мусить добре знати. Готуючись до уроку, вчитель (особливо початківець) обмірковує його зміст, методику, враховує особливості сприймання учнів певного віку, класу, власні можливості. Отже, зміст професійної компетентності - це знання предмета, методики його викладання, педагогіки і психології, а також володіння голосом та грою на музичному інструменті. Вчитель повинен вміти синтезувати матеріал для успішного розв' язання педагогічних задач, аналізувати педагогічні ситуації і т.д.

Знання педагога - не сума засвоєних дисциплін, а усвідомлена система, 3 власними оцінками, критичними поглядами.

Для того, щоб викликати в учнів певне ставлення до музичного явища, предмета, що обговорюється на уроці, вчитель висловлює своє розуміння проблеми, свої міркування. Звучить: “ $Я$ гадаю...", “Мені здається...”, А буває й так: студент на педагогічній практиці точно передає думку 3 підручника, розповідає грамотно, послідовно, а думки класу не дістає у відповідь. Так інколи вчитель забуває педагогічну істину: якщо сам не розкриваєшся перед учнями, не даєш їм проникнути у світ своїх почуттів, думок, марно очікувати щирих відповідей, а саме на уроках музики. Таке навчання не стає розвитком творчого потенціалу учнів, воно перетворюється просто у процес “накопичення знань”. Майстерність педагога - в натхненності знання, яке не переноситься 3 книжок у клас, а подається як власний погляд на світ. На грунті професійних знань формуються принципи і правила, які кожний педагог виробляє на власному досвіді. Слід зауважити, що складність навчання педагогамузиканта, набуття професійності полягає і втому, що знання, вміння і навики, мають формуватися на всіх рівнях: методологічному, теоретичному, методичному, технологічному. Це потребує розвиненого професійного мислення, здатності добирати, аналізувати і систематизувати здобуті знання у досягненні педагогічної мети.

Проте швидкість набуття професійності не регламентується лише накопиченням знань. Справді, студентові, який добре вчиться в педагогічному навчальному закладі, не завжди легко на педагогічній практиці в школі, яка вимагає творчої активності. $€$ індивідуальні передумови успішної діяльності, стимулятори професійного зростання - музичні здібності. Аналіз творчих здібностей здійснено у багатьох дослідженнях, а спираючись на них можна виокремити шість здібностей до педагогічної діяльності:

1. Комунікативність - готовність легко вступати в контакт;

2. Професійна проникливість - педагогічна інтуїція;

3. Здатність активно впливати на іншу особистість;

4. Емоційна стабільність - здатність володіти собою;

5. Оптимістичне прогнозування - передбачення розвитку особистості;

6. Креативність - здатність до творчості.

Здібності до музично-педагогічної діяльності можна оцінити залежно від того, як швидко йде професійне навчання. Поле тяжіння вмілого 
педагога поширюються передусім на нього самого - самовладання, емоційна стабільність особистості дають змогу володіти ситуацією.

Ще один елемент музично-педагогічної діяльності - це педагогічна техніка, як форма організації поведінки вчителя. Знання, спрямованість і здібності без умінь, без володіння способами дій, а саме - голосом, грою на музичних інструментах не $\epsilon$ гарантією високих результатів. Педагогічна техніка на уроках музики - це вміння використовувати свій талант і здібності, це прийоми володіння собою та прийоми впливу на інших.

В оволодінні педагогічною майстерністю можна визначити кілька рівнів:

1. Елементарний - у вчителя наявні лише окремі якості музичної професійної діяльності. Найчастіше - це володіння знаннями для виконання педагогічної дії, володіння предметом викладання. Проте через брак спрямованості на творчий розвиток учня, техніки організації діалогу, продуктивність його навчально-виховної діяльності є невисокою.

2. Базовий рівень - учитель володіє основами музично-педагогічної майстерності: педагогічні дії зорієнтовані, стосунки з учнями і колегами розвиваються позитивно, добре засвоєно предмет викладання, проведення загальних творчих заходів та методично впевнено і самостійно організовано навчально-виховний процес на уроці.

3. Досконалий рівень - характеризується чіткою спрямованістю дій учителя музики, їх високою якістю, діалогом у спілкуванні. Педагог самостійно планує й організовує свою діяльність на тривалий проміжок часу, не тільки на уроках, але й на різноманітних музичних, літературних вечорах, концертах, маючи головним завданням розвиток особистості учня [5].

Характеризується ініціативністю і творчим підходом до організації професійної діяльності. Вчитель музики самостійно будує оригінальні, педагогічно доцільні прийоми взаємодії. Сформовано індивідуальний стиль професійної діяльності.

Завдання закладу вищої освіти - допомогти студентові опанувати основи майстерності (співу, диригування, гри на музичному інструменті) для усвідомленого i продуктивного початку професійної діяльності: спрямувати навчання, дати грунтовні знання з диригування, співу, з історії та теорії музики, розвинути педагогічні здібності, озброїти технікою взаємодії, підготувати до професійного аналізу різноманітних музичнопедагогічних ситуацій.

Педагогічна діяльність складається з ланцюга педагогічних ситуацій. Їх створюють як учитель, так і учні, спонтанно і спеціально.

Вчитель усвідомлює педагогічні ситуації і формулює для себе завдання:

1. Як виховати ушколярів почугтя відповідальності, організованості;

2. Розробити засоби обліку і контролю знань, активізувати пізнавальну діяльність на уроках;

3. Реагувати не те, що хтось не вивчив, був неуважним на уроках, чи запізнився.

Засобами педагогічної техніки вчитель мусить виявити перед учнями силу свого завдання допомогти, підтримати. Важливо читати в душах учнів їхні думки і почуття, щоб бачити наслідки своїх дій.

Висновки. Навчально-виховний процес у школі - явище складне, багатогранне і динамічне. Щоб цей процес був ефективним, у вчителя і учня мають переважати позитивні естетичні почуття як показник людяності, гуманності, творчості, а відтак працездатності та ії результативності. Цей бік педагогічної професії стикається, 3 мистецтвом, що завжди є поєднанням таланту та майстерності.

Досвід музично-педагогічної діяльності показує, що вчителеві недостатньо знань основ науки і методики навчально-виховної роботи. Адже всі його знання і практичні вміння, можуть передаватись учням лише завдяки живому і безпосередньому спілкуванню 3 ними. Для багатьох вчителів очевидною є істина: учні часто переносять ставлення вчителя на предмет, який він викладає на цих стосунках вибудовується процес навчання і виховання, через них відбувається проникнення педагога в душевний світ учнів, щоб виробити у них навички співтворців власної особистості.

Майстерність педагога-музиканта визначається трьома складниками: теорією, технікою і методами роботи над музичним матеріалом, його організацією і впровадженням у дію. Якщо теорію можна опанувати відносно легко, і швидко, то методикою музичного виховання слід оволодіти поступово, поетапно, напруженим тренуванням як основою професійної підготовки вчителя. Систематичним тренуванням техніку слід доводити до рівня рефлексорної діяльності.

Дослідники проблем поведінки педагогів пропонують дотримуватись певних правил дії спілкування $з$ дітьми:

- до класу заходити бадьорим, впевненим, енергійним;

- спілкування, продуктивне, впевнене;

- яскраво виражена готовність до спілкування;

- в класі створювати потрібний емоційний настрій; 


\section{РЕПЕРТУАРНАПАЛІТРА УКРАЇНСЫКИХ ХОРОВИХ КОЛЕКТИВІВ}

(на прикладі Галицького камерного хору)

- здійснювати керування спілкуванням;

- мова має бути яскрава, образна, а міміка виразна;

- грунтовне знання матеріалу;

- чітке дотримання міри.

Той, хто на все життя обирає професію вчителя музичного мистецтва, має володіти хоча б трьома особливостями: умінням шанувати і любити людей більш за себе, умінням усе життя поповнювати знання і збагачувати свій досвід, теоретичний, практичний, естетичний, умінням передавати цей досвід учням.

\section{ЛІТЕРАТУРА}

1. Вишневський О. Українська педагогіка на старті реформ. Дрогобич. 2015.

2. Гончаренко С. Український педагогічний словник. Київ. 1997.

3. Кан-Калик В. Учителю об педагогическом мышлении. Москва. 1987.

4. Макаренко А. Деякі висновки з мого педагогічного досвіду. Твори т.5, т.7.
5. Педагогічна майстерність / Підручник (за редакцією І.З.Язюка). Київ. 1997. 1976.

6. Сухомлинський В. Сто порад учителю. Т.5. Київ.

\section{REFERENCES}

1. Vyshnevskyi, O. (2015). Ukrainska pedahohika na starti reform [Ukrainian pedagogy at the start of reforms]. Drohobych. [in Ukrainian].

2.Honcharenko, S.(1997). Ukrainskyipedahohichnyi slovnyk [Ukrainian Pedagogical Dictionary]. Kyiv. [in Ukrainian].

3. Kan-Kalik, V. (1987). Uchitelyu ob pedagogicheskom myshlenii [For teacher concerning the pedagogical thinking]. Moscov. 1987. [in Russian].

4. Makarenko, A. Deiaki vysnovky z moho pedahohichnoho dosvidu [Some conclusions from my pedagogical experience]. Writings. Vol.5, Vol.7. [in Ukrainian].

5. Pedahohichna maisternist (1997). [Pedagogical skill]. (Ed.). I.Z. Iaziuk. Kyiv. [in Ukrainian].

6. Sukhomlynskyi, V. (1976). Sto porad uchyteliu [One hundred tips to the teacher]. Vol.5. Kyiv. [in Ukrainian].

Стаття надійшла до редакції 01.04.2019

УДК

DOI:

Оксана Волох, старший викладач кафедри методики музичного виховання і диригування Дрогобицького державного педагогічного університету імені Івана Франка

\section{РЕПЕРТУАРНА ПАЛІТРА УКРАЇНСЬКИХ ХОРОВИХ КОЛЕКТИВІВ (на прикладі Галицького камерного хору)}

У статті коротко простежено творчий шлях Галицького камерного хору від часів його заснування в контексті становлення репертуарної концепиії колективу. Визначено генеральну творчу мету художнього керівникахору, яка стала поштовхом і головним фактором репертуарної концепиї̈; виявлені головні фактори та шляхи її реалізації: гастрольні та конкурсні поӥзки, формування моделей кониертних програм, творчих проектів, робота з музикознавиями, творча співпрачя зі світовими фірмами тощяо.

Ключові слова: професіоналізм; репертуарна палітра; творча мета; хорове виконання; камерний Галицький хор.

Jim. 6.

Oksana Volokh, Senior Lecturer of the Methodology of Musical Education and Conducting Department Drohobych Ivan Franko State Pedagogical University

\section{REPERTOIRE PALETTE OF UKRAINIAN CHOIR COLLECTIVES}

\section{(on the example of Galycian chamber choir)}

The article briefly reviews the creative path of the Galician Chamber Choir since its foundation in the context of the formation of the repertoire concept of the collective. The general creative goal of the artistic director of the choir was determined, which became the impetus and the main factor of the repertoire concept; The main factors and ways of its realization are revealed: tours and competitive trips, forming of models of concert programs, creative projects, work with musicologists, creative cooperation with world firms, etc.

The leading role in the professionalization of choral performance was played by choral groups at musical societies, which held active concert activities, developed secular choral art and significantly influenced the increase of the professional level of choral performance in Western Ukraine. The organizers of the choirs were bright personalities - talented choristers, who had the ability to create interesting collectives, encouraging singing of the general population.It is emphasized that exactly in chamber choir performance the highest level of professional 